\title{
HRM Practices Affecting Extrinsic and Intrinsic Motivation of Knowledge Receivers and their Effect on Intra-MNC Knowledge Transfer
}

Minbaeva, Dana

Document Version

Final published version

Publication date:

2008

\section{License}

CC BY-NC-ND

Citation for published version (APA):

Minbaeva, D. (2008). HRM Practices Affecting Extrinsic and Intrinsic Motivation of Knowledge Receivers and their Effect on Intra-MNC Knowledge Transfer. Center for Strategic Management and Globalization. SMG Working Paper No. 12/2008

Link to publication in CBS Research Portal

\section{General rights}

Copyright and moral rights for the publications made accessible in the public portal are retained by the authors and/or other copyright owners and it is a condition of accessing publications that users recognise and abide by the legal requirements associated with these rights.

Take down policy

If you believe that this document breaches copyright please contact us (research.lib@cbs.dk) providing details, and we will remove access to the work immediately and investigate your claim. 
HRM PRACTICES AFFECTING EXTRINSIC AND INTRINSIC MOTIVATION OF KNOWLEDGE RECEIVERS AND THEIR EFFECT ON INTRA-MNC KNOWLEDGE TRANSFER

Dana Minbaeva

SMG WP 12/2008

March 10, 2008 
SMG Working Paper No. 12/2008

March 10, 2008

ISBN: 978-87-91815-25-6

Center for Strategic Management and Globalization Copenhagen Business School

Porcelænshaven 24

2000 Frederiksberg

Denmark

www.cbs.dk/smg 


\title{
HRM PRACTICES AFFECTING EXTRINSIC AND INTRINSIC MOTIVATION OF KNOWLEDGE RECEIVERS AND THEIR EFFECT ON INTRA-MNC KNOWLEDGE TRANSFER
}

\section{Dana Minbaeva, Ph.D.}

Center for Strategic Management and Globalization

Copenhagen Business School

Porcelaenshaven 24, $1^{\text {st }}$ floor, DK2000 Copenhagen F, Denmark Tel. (45) 38152527. Fax (45) 38153035. Email: dm.smg@cbs.dk

\begin{abstract}
This paper explores why and how HRM matters for knowledge transfer within multinational corporations. It is built upon the premise that there are certain HRM practices influencing extrinsic and intrinsic motivation of knowledge receivers. It is found that complementarity among HRM practices exists but does not always have a positive effect on knowledge transfer. Three hypotheses derived from these arguments are tested on data from 92 subsidiaries of Danish multinational corporations located in 11 countries.
\end{abstract}

Key words: Extrinsic/intrinsic motivation, HRM practices, knowledge transfer in MNCs 


\section{INTRODUCTION}

Previous research has found that multinational corporations (MNCs) can institute various organizational policies and practices to overcome barriers associated with knowledge transfer determinants, thereby facilitating internal knowledge transfer (e.g. Persson, 2006). In particular, it has been suggested that human resource management (HRM) practices could influence the degree of intra-MNC knowledge transfer if the HRM practices employed are aimed at enhancing the capacity of organizational members to contribute to knowledge-related organizational goals (Pucik, 1998; Tsang, 1999; Minbaeva et al., 2003). Overall, there is a shared assumption that a nonnegligible part of the observed variation in the degree of knowledge transfer can be ascribed to variation in the employment of HRM practices.

However, more work needs to be done to explain theoretically why and how HRM and knowledge transfer are linked. While there have been extensive discussions concerning the implications of the management and governance of knowledge for theory building in other fields of management research (e.g., Osterloh and Frey, 2000; Grandori and Kogut, 2002), this has not been the case in the HRM field. HRM scholars themselves have acknowledged the fact that the field of HRM lacks the view of knowledge as an organizationally shared, accessible, and transferable resource that needs to be managed (Wright, Dunford and Snell, 2001: 714). Nonetheless, given its concern with the identification, development, deployment, and rewarding of human capital (knowledge embodied in humans) and its services, the HRM field seems to address directly the issues of governance and knowledge management (Foss, 2007).

Despite an increasing interest in the subject, it is surprising how little empirical 
research has actually been conducted on the topic (Foss and Pedersen, 2002). The existing empirical work has been criticized for focusing exclusively on the individual HRM practices and their isolated effect (Laursen and Foss, 2003). That could be a serious limitation since HRM is defined as "a set of distinct but interrelated activities, functions, and processes that are directed at attracting, developing and maintaining (or disposing of) a firm’s human resources” (Lado and Wilson, 1994, p.701; emphasis added). Therefore, it has been suggested that future research should consider the complementary effect of HRM practices on the degree of knowledge transfer. To advance the field, it was recommended that the groups of HRM practices should be identified theoretically, rather than by relying on statistical techniques such as factor and cluster analysis (Guest, 1997). In this regard, the literature points to the possibility of expanding the framework linking HRM practices and knowledge transfer by introducing individual-level mediating variables. Those variables are "the very outcomes that seem to have originally guided the construction of HR practice items” (Gerhart, 2005: 183) and individual-level variables explaining organizational-level knowledge processes (Argote, McEvily and Reagans, 2003).

The paper considers the motivation of knowledge receivers (a subsidiary's employees) as a mediating variable that helps explain why and how HRM practices affect intra-MNC knowledge transfer. I have chosen to focus on motivation because despite a general consensus among theoretical and conceptual researchers that a strong willingness on behalf of knowledge receivers to absorb new knowledge increases the likelihood of successful knowledge transfer (e.g. Argote, McEvily and Reagans, 2003), empirical studies on the role of employees' motivation in knowledge transfer have reported mixed results. It is suggested that using a more nuanced measure of motivation would enable researchers to develop unique insights into how 
HRM practices affect motivation of knowledge receivers and ultimately knowledge transfer. Towards this goal, the existing literature on motivation of knowledge receivers and knowledge transfer is reviewed and the differences between extrinsic and intrinsic motivation are introduced. Then it is argued that there are certain HRM practices that influence the extrinsic and intrinsic motivation of knowledge receivers. The degree of knowledge transfer to the subsidiary could be managed (or governed, see Foss, 2007) via the application of those HRM practices. Three hypotheses considering the individual and system effects of HRM practices are put forward and tested on the dataset of 92 subsidiaries of Danish based MNCs located in 11 countries. At the end of the paper, the results are discussed and future research perspectives are presented.

\section{THEORETICAL BACKGROUND}

It has been argued that the competitive advantage that MNCs enjoy over national firms is contingent upon the MNCs' ability to exploit knowledge internally across organizational units. A common theme in this line of research is that MNCs can develop knowledge in one location and then exploit it in other locations, requiring an internal transfer of knowledge. Notwithstanding the significant progress made towards understanding the process of knowledge transfer within MNCs (for a review, see Minbaeva 2007), there are several areas that have been bypassed. For instance, until recently, intra-MNC knowledge transfer has seldom been treated endogenously (Foss and Pedersen, 2002). Yet, without clear indications as to how the intra-MNC knowledge transfer process could be managed, managers are none the wiser in being informed that knowledge transfer is conducive to competitive advantage.

One significant theoretical development in regard to comprehending how internal 
knowledge transfer could be influenced and directed is the emerging knowledge governance approach (KGA) (Grandori, 2001; Foss, 2007). It focuses on the interplay between knowledge-based contingency factors and organizational routines such as reward systems, coordination mechanisms and standard operating procedures. According to the KGA, an organizational attempt to positively influence knowledge transfer should begin with the employment of formal organizational mechanisms, because these (in contrast to informal organizational mechanisms) are levers that are directly available to managers. As Foss (2007) explains, formal organizational mechanisms are deployed in the belief that influencing the conditions of individual actions in a certain manner will lead employees to make those decisions that when aggregated lead to favorable organizational outcomes (e.g. knowledge transfer).

In this paper, I consider HRM practices to be formal organizational mechanisms which managers could employ to facilitate intra-MNC knowledge transfer. To identify the mechanisms, the KGA asserts the need to build micro-foundations grounded in individual action for organizational knowledge-based phenomena (Felin and Foss, 2005). Towards this goal, in the following, motivation of knowledge receivers is considered the individual-level mediating variable explaining why and how HRM and knowledge transfer are linked.

\section{Motivation of knowledge receivers and knowledge transfer}

Szulanski (1996) argues that "the movement of knowledge within the organization is a distinct experience, not a gradual process of dissemination, and depends on the characteristics of everyone involved" (p. 28). Therefore, the degree of internal knowledge transfer depends on various factors, among which the motivation of knowledge receivers has attracted considerable attention (e.g. Szulanski, 1996; Gupta 
and Govindarajan, 2000). However, as pointed out earlier, empirical studies on the role of employees’ motivation in knowledge transfer have reported mixed results._For example, Szulanski (1996) defined a knowledge receiver's lack of motivation as a general reluctance to accept knowledge from the outside. However, this was not supported by the results of the study, which showed that motivational factors were superseded by (among other things) the ability of knowledge receivers. In contrast, Gupta and Govindarajan (2000) found that knowledge transfer from headquarters to the focal subsidiary is higher when the subsidiary's motivational disposition to acquire knowledge is high. The lack of consistency in the results may be ascribed (among other things) to the fact that neither of the reviewed studies distinguishes between two particular types of motivation: extrinsic and intrinsic. That could be a serious limitation since not only the introduction of the distinction but also the dynamics of interplay between extrinsic and intrinsic motivation help "to determine which factors influence the intensity and quality of the production of intangible firmspecific pool resources, especially tacit knowledge” (Osterloh, Frost and Frey 2002, p. 67). Moving beyond a unitary view of motivation is beneficial because “...people are moved to act by very different types of factors, with highly varied experiences and consequences” (Ryan and Deci, 2000).

The two kinds of motivation are very different. Extrinsic motivation occurs when employees are able to satisfy their needs indirectly through financial rewards and incentives for past performance. Extrinsic motivation results from incentives for behaving in a certain way based on the use of a price system. Extrinsic motivation can be used to coordinate resources by linking employees' monetary motive to the goal of the organization (Osterloh and Frey, 2000). The main characteristic of employees who are externally motivated towards knowledge sharing is that some external 
contingency, which is valued and expected to be obtainable, drives their involvement in knowledge sharing. For example, Cabrera and Cabrera (2002) argue that the process related to decisions about whether to engage in knowledge sharing activities bears resemblance to a cost-benefit analysis.

Intrinsic motivation is fostered by commitment to the work itself; "there is no apparent reward except the activity itself” (Deci, 1975, p. 23). Intrinsically motivated employees engage in activities to feel competent and self-determined in relation to the environment. Intrinsic motivation has advantages over extrinsic motivation in organizational activities that demand creativity and learning on the part of employees when organizational goals are unclear and when the exchange rests on highly incomplete contracts (Frey, 1997). Several scholars argue that especially intrinsic motivation has a positive effect on knowledge sharing (Cabrera, Collins and Salgado, 2006; Mudambi, Mudambi and Navarra, 2004; Osterloh and Frey, 2000)

Osterloh and Frey (2000) point out that both kinds of motivation are crucial for transferring knowledge. They also note that there is a systematic dynamic relationship between the two types of motivation: intrinsic motivation and extrinsic motivation are not additive, but rather interactive (Osterloh and Frey, 2000). Further, there might be a negative effect of introducing extrinsic rewards to people who are already intrinsically motivated (Frey, 1997). In that situation, extrinsic motivation is said to crowd out intrinsic motivation (Osterloh, Frost and Frey, 2002; Frey and Jegen 2001). The crowding out effect is especially significant when the monetary compensation is perceived as controlling and hence creates the feeling of being controlled from outside. Similarly, Janssen and Mendys-Kamphorst (2004) conclude that introducing financial incentives to agents to contribute to a socially desirable outcome tends to 
decrease the number of contributions.

Whether intrinsic or extrinsic, motivation may be driven by the application of HRM practices (see e.g. Huselid, 1995). The next section distinguishes between HRM practices aimed at "keeping a person on the job” and HRM practices employed to “motivate him to perform effectively on that job” (Deci, 1975). The former increases extrinsic motivation while the latter affects intrinsic motivation. I also argue that one should expect negative HRM complementarity on the degree of knowledge transfer, since HRM practices influencing extrinsic motivation may crowd out the effect of HRM practices influencing intrinsic motivation.

\section{HYPOTHESES DEVELOPMENT}

\section{HRM practices affecting extrinsic motivation}

To keep a person on the job, an organization needs to satisfy his/her needs. That could be achieved through the use of external reward systems that compensate subsidiary employees for the value of their job and their personal contribution to organizational performance. Well-developed compensation systems may include: (competitive) salary, bonuses, fringe benefits, paid-for education, etc. This system must be administered not unconditionally but rather selectively so the more effective an employee's performance, the more rewards the employee receives (Deci, 1975). Therefore, in order for the reward systems to motivate employees, an external control should be in place. The control is achieved through a performance appraisal system. An integrated part of most performance appraisal systems is the evaluation of past performance, identification of gaps between employees' past performance and management expectations, and the establishment of courses of action that aim to fulfill the identified gaps. 
In the literature on intra-MNC knowledge transfer, rewards were found to have a positive effect on the motivation of the absorptive capacity of a subsidiary's employees and hence knowledge transfer to that subsidiary (Minbaeva et al., 2003). As Bock et al. assert, “every organization we interviewed had implemented monetary incentives, points towards promotion, or both as extrinsic motivators for knowledge sharing” (2005: 91). One example is Siemens' ShareNet, which measured and rewarded employees for knowledge sharing. Especially in the beginning, when ShareNet was in its infancy, the reward system was designed to create a critical mass of content by making users aware of the system and encouraging contributions. This was accomplished through a competitive reward structure based on the number of contributions made (Nielsen and Ciabuschi, 2003).

Hypothesis 1. The more the subsidiary employs HRM practices affecting extrinsic motivation (such as performance management systems and rewards), the higher the degree of knowledge transfer to that subsidiary.

\section{HRM practices affecting intrinsic motivation}

Performance-based rewards are not enough to motivate employees to perform effectively on their job. Intrinsically motivated employees can derive satisfaction from doing an effective job per se: "they can become ego-involved with their jobs, emotionally committed to doing them well and take pride from evidence that they are effective in furthering the objectives of the company” (Vroom and Deci, 1970, p. 15). A number of studies on intrinsic motivation have shown that intrinsic motivation is more conducive to creative tasks in general and knowledge transfer in particular (Osterloh, Frost and Frey, 2002).

Management cannot administer intrinsic motivation directly. Instead, as the 
behavioral school of participative management (Theory Y) suggests, efforts should be made to structure jobs in a way that gives employees various opportunities to participate in decision making on important issues related to them. Furthermore, jobs should be designed to be challenging and interesting (Deci, 1975). What HRM practices could help organizations to achieve both? Flexible working practices and job design could be beneficial for employees, allowing them to balance their work and other aspects of their lives. Horizontal and vertical transfers may help organizations to better allocate individual needs for growth and development. In addition to the learning experience and improved competencies, employees achieve a higher degree of self-actualization and involvement. In MNCs, international rotation helps to increase the level of integration and interunit trust (Edstrom and Galbraith, 1977), but at the same time exposes local employees to international challenges and demanding assignments. In sum, intrinsic motivation could be influenced by HRM practices with emphasis on self-actualization, self-control and self-regulation. The aim is to create conditions under which "effective performance can be a goal rather than a means to the attainment of some other goals” (Vroom and Deci, 1970, p. 16). By applying HRM practices in which the incentives are in the task or job itself, organizations would be able to give intrinsically motivated employees the freedom to determine how to do the job, where to search for needed competencies, etc.

Hypothesis 2. The more the subsidiary employs HRM practices affecting intrinsic motivation (such as job design, flexible working arrangement, career development), the higher the degree of knowledge transfer to that subsidiary.

\section{Complementarity}

Traditionally, complementarity is defined as when doing more of one thing increases 
the returns of doing more of the others (Milgrom and Roberts 1990, 1995). It assumes an effect on performance from complex interactions among several practices, reinforcing the effect of other practices in either a positive or a negative direction. Whittington et al. (1999) argue that organizational practices that are associated with positive performance when employed individually may be found to have negative effects when combined with their complements. Negative complementarity occurs when the elements of the system destroy value rather than create it (Becker and Huselid, 1996). In the following I argue that HRM practices that influence the two types of motivation applied in a complementary way affect knowledge transfer negatively due to the crowding out effect of extrinsic and intrinsic motivation.

As argued earlier, the two types of motivation are neither independent nor additive. What happens if an intrinsically motivated person begins to receive an extrinsic reward for his actions? According to Motivation Crowding Theory, when two types of motivators are applied simultaneously, external intervention via monetary incentives or punishments may undermine or crowd out intrinsic motivation (Frey and Jegen, 2001). According to Kohn (1993), extrinsic rewards undermine employees' interest in their jobs. Specifically, task-contingent rewards tend to negatively impact intrinsic motivations. Frey (1997) has also pointed out that there might be a negative effect of introducing extrinsic motivation to people who are already intrinsically motivated. Evidence of the crowing out effect has been found in laboratory experiments (Deci and Koestler, 1999). Thus, HRM practices that support intrinsic motivation of knowledge receivers may create a crowding out effect when applied together with those practices that support extrinsic motivation.

Hypothesis 3. HRM practices influencing intrinsic and extrinsic motivation 
are complementary; their complementarity has a negative effect on the degree of knowledge transfer to the subsidiary.

\section{Data}

The hypotheses are tested on the dataset of 92 subsidiaries of Danish MNCs located in 11 countries. For the construction of the dataset, the Hermes CD Direct from KOB (Kobmandstandes Oplysnings Bureau) was used. ${ }^{1}$ The database query was initiated by selecting those firms that were headquartered in Denmark, and then reducing the sample to those that had two or more subsidiaries abroad. The procedure resulted in a list that was cross-checked with the Borsen $500^{2}$ in order to ensure that the population was as complete and relevant as possible. The number of the MNCs included in the sample was further limited to those whose subsidiaries employ more than 30 employees, as it is commonly stated that small-scale companies, in general, and small subsidiaries, in particular, do not employ a wide range of formal HRM practices (Miner and Crane, 1995).

Subsidiaries' contacts were obtained from the headquarters in Denmark and from the foreign commercial sections of the Danish Embassies in Germany, Sweden, USA, China, and Russia. Those countries were chosen due to the internationalization trend of Danish MNCs. A majority of the Danish subsidiaries are located in the close vicinity of Denmark (Germany and Sweden) and in those countries, which take

\footnotetext{
${ }^{1}$ The KOB dataset is a comprehensive, continuously updated dataset of domestic and international Danish firms (www.kob.dk). 2 Borsen is the Danish business sector's global, national and regional newspaper. Every year the newspaper publishes an annual status report of Danish businesses (www.borsen.dk)
} 
majority of Danish exports (USA). Recently, two more regions have become important areas of establishment - Eastern Europe and Asia.

The final dataset consisted of 305 Danish subsidiaries. Questionnaires were addressed to a HRM Manager/General Manager of each subsidiary. If the manager approached was unable to complete the survey, it was up to him/her to forward the questionnaire to another senior/middle level manager with sufficient knowledge of the themes of the study.

Due to time and cost considerations, a web-based survey was chosen to collect the necessary data. The respondents were sent a cover letter via email. The cover letter/email explained the purpose of the survey, described the research process and analysis procedures and provided straightforward directions about how to complete the questionnaire. Additionally, a webpage was established to back up the survey. The respondents were invited to visit the webpage to read more about the survey topics and related themes. The link to the questionnaire was provided within the text of the cover letter/email. The survey was put on the webpage, which could only be accessed through that link. There were no links to it from other webpages. This step restricted unwanted answers and decreased the risk of potential error.

The above strategy resulted in a response rate of 30 percent (92 out of 305 subsidiaries). There were 20 subsidiaries located in Germany, 17 in the USA, 15 in Russia, 14 in China, ten in Sweden, six in the UK, six in France and one each in Sri Lanka, Philippines, Spain and Portugal. A majority of the subsidiaries included in the sample were located in the close vicinity of Denmark: almost 40 percent of all subsidiaries were located in Germany, Sweden and the UK. 30 of the 92 subsidiaries employed more than 100 employees. More than half of the subsidiaries in Russia were 
large. Twenty-five percent of the total sample of subsidiaries represented the manufacturing sector, among which the majority of production subsidiaries were located in the USA and Asia. The rest of the subsidiaries represented mainly sales and marketing functions. Among the subsidiaries included in this dataset there were only four subsidiaries where R\&D activities comprised more than 15 percent: two located in China, one in Russia, one in Sweden and one in the UK. The subsidiaries were established through various modes of entry. Only one third of the sample were Greenfield subsidiaries. The European subsidiaries were owned by shared capital while foreign capital constituted the major part of the ownership packages of the remaining subsidiaries. All subsidiaries had some experience in working internationally. Exceptions to this were subsidiaries located in Sweden. This is not surprising since Denmark and Sweden are neighboring countries sharing many similarities in the ways business is conducted and having comparatively small cultural differences.

\section{Measures}

The operationalization of the variables is presented in Table 1. All variables were captured through perceptual, self-report measures. Self-report measures are used in the majority of organizational behavior studies. Despite their obvious weaknesses, self-report questionnaires are especially useful when the constructs they measure are perceptual in nature (for instance, attitudes, perceptions, understanding, affective responses, etc). They can provide a picture of how people perceive and feel about their job-related behavior (Spector, 1994, Schmitt, 1994; Howard, 1994). Howard (1994) argues that the use of perceptual, self-report measures is the most suitable methodology for the study of human behavior and, when employed within a sensible 
design, may even be superior to other approaches.

\section{- INSERT TABLE 1 ABOUT HERE -}

The understanding of the operationalization was checked during the piloting of the questionnaire. To deal with reliability of measures, the inter-rate reliability test ${ }^{3}$ was conducted prior to the analysis (Gupta and Govindarajan, 2000). Responses on some variables were obtained from both the MNC headquarters and their overseas subsidiaries. One of the questionnaires was sent to the headquarters of the Danish MNCs and addressed to a Senior HRM Manager/Personnel Director, who was asked to name a subordinate (a HRM Manager/Personnel Director of the subsidiary) with whom he or she closely collaborated. In turn, the person indicated was approached with the similar questionnaire. In 21 cases (about $20 \%$ of the total population), two groups of respondents answered the same questions about knowledge receivers' ability and motivation to absorb knowledge. Although the subsidiary respondents had a tendency to rate the ability and motivation of knowledge receivers higher than the respondents from headquarters, the overall correlation between the ratings from HQ and their relative subsidiaries are positive and significant.

Degree of knowledge transfer. The degree of knowledge transfer was defined at the beginning of the questionnaire as the extent to which subsidiary employees received knowledge transferred to the subsidiary from the rest of the MNC (HQ and sister

\footnotetext{
${ }^{3}$ The inter-rater reliability (or inter-observer reliability) test is one of four general classes of reliability estimates and the best one to estimate reliability when the measure is an observation. It is used to assess the degree to which different respondents give consistent estimates of the same phenomenon. When the measure is continuous (as in our case), the best way is to calculate the correlation between the ratings of two respondents.
} 
subsidiaries). The operationalization was adopted from Gupta and Govindarajan (2000). Data was collected on the following items: marketing know-how, distribution know-how, packaging design/technology, product designs, process designs, purchasing know-how, and management systems and practices. Respondents were asked to evaluate the degree of knowledge transfer from the sister subsidiaries and from the HQ for each aspect using a five-point Likert-type scale, where 1 indicated very low use of knowledge and 5 indicated substantial use of knowledge. Responses were averaged to yield a composite index reflecting the degree of knowledge transfer to the focal subsidiary from the rest of the MNC. Cronbach Alpha - a coefficient of reliability - was used to measure how well a set of items (or variables) measures a single one-dimensional latent construct. For DoKT, Cronbach Alpha for 14 items was 0.84

HRM practices. Measures for HRM practices were adopted from previous studies by Huselid (1995), Huselid, Jackson and Schuler (1995) and Delaney and Huselid (1996). Measures were then cross-checked with the conclusions of theoretical papers, findings from the case studies and limited empirical work on the link between HRM and knowledge-related outcomes. On the 5-point Likert-type scale (from 1 - never to 5 - always), respondents were asked to indicate the degree to which each of eight HRM practices were employed within the subsidiary (see Table 1).

Following Huselid (1995), HRM practices were factor analyzed using the principal component analysis with varimax rotation. Using the "bundles" of internally consistent HRM practices (identified through factor analysis), rather than the averaged scores of individual HRM practices, made it possible to capture "the system effect” of HRM practices (Huselid, 1995; Huselid, Jackson and Schuler, 1995). Two 
groups of HRM practices with eigenvalues more than 1 emerged from the analysis HRM practices influencing extrinsic motivation (HRM EXTR) and HRM practices influencing intrinsic motivation (HRM INTR). Factor loadings for each factor are reported in Table 2 .

\section{- INSERT TABLE 2 ABOUT HERE -}

Control variables. The studies on the influence of organizational practices on motivation of knowledge receivers identified other factors that could influence knowledge transfer to the subsidiary. Among them are subsidiary age, mode of entry and ownership (Lyles and Salk, 1996; Mowery, Oxley and Silverman, 1996; Lane, Salk and Lyles, 2001; Minbaeva et al., 2003). Thus, when testing the hypothesis, it was important to control for the potential effects of the above-mentioned factors. No predictions were made on the influence of the control variables on the results of hypothesis testing.

The fourth control variable was the ability of knowledge receivers. Cohen and Levinthal (1990) assume that receivers’ ability to recognize, value and assimilate new knowledge is more likely to be developed and maintained when the external knowledge that an organization wishes to exploit is closely related to the organization's prior knowledge base. The term refers to the existing individual units of knowledge available within the organization (Szulanski, 1996, 2003; Kim, 2001). Employees need to have the combinations of skills that enable them to find, acquire, manage, share, and apply the knowledge that the organization needs to assimilate and use to achieve the higher degree of knowledge transfer. The measures were adopted from Minbaeva et al. (2003): respondents were also asked to evaluate the ability of subsidiary employees to absorb new knowledge, not as a measure of individual ability 
but as a measure of subsidiary employees' overall ability to absorb knowledge (see Table 1). It was expected that knowledge receivers' ability will affect the degree of knowledge transfer positively.

\section{Results}

The correlation matrix is presented in Table 3. Some associations between the independent variables are apparent; however, none of the correlations indicate multicollinearity - for all variables $\mathrm{r}<0.5$ (tolerance $0.721-0.968$; VIF 1.033 1.388).

\section{- INSERT TABLE 3 ABOUT HERE -}

Model 1 in Table 4 reports the results of the regression analysis with control variables. Unstandardized coefficients are reported. The model is significant with an adjusted R-square of 0.090. Among the control variables, ABILITY has a positive and significant effect on the dependent variable. That effect holds in all other models.

\section{- INSERT TABLE 4 ABOUT HERE -}

To test Hypothesis 1, HRM EXTR was regressed on the dependent variable while controlling for MODE, OWNERSHIP, AGE and ABILITY (see Model 2 in Table 4). The model is highly significant $(\mathrm{p}<0.001)$ with an adjusted R-square of 0.224 . The use of HRM practices related to extrinsic motivation has a positive and significant effect $(\mathrm{p}<0.01)$ on knowledge transfer to the focal subsidiary. Hypothesis 1 is supported by the data.

Model 3 in Table 4 reports the results for Hypothesis 2. As expected, the effect of HRM INTR was positive but insignificant. The model is slightly significant $(\mathrm{p}<0.10)$ with an adjusted R-square of 0.095 . 
To test the complementarity hypothesis (Hypothesis 3), this study follows Ichniowski, Shaw and Prennushi (1997) and Cappelli and Neumark (2001) who advocate a multiplicative approach (i.e. testing for interactive effects): "to examine the importance of sets of highly correlated and presumably complementary HRM practices, one must examine the effects of interactions among the practices” (Ichniowski, Shaw and Prennushi, 1997: 296). Along with the interactive effect, Cappelli and Neumark (2001) recommend entering the main effect of each of the independent variables. The hypothesis on negative complementarity between HRM INTR and HRM EXTR is tested in Model 4 (Table 4). Individually, HRM EXTR and HRM INTR continue to have a positive and significant effect on the dependent variable ( $<<0.001$ and $\mathrm{p}<0.10$ respectively). However, their interaction effect has a negative sign and is significant at $\mathrm{p}<0.05$. Hypothesis 3 is supported. The model is significant $\left(\mathrm{p}^{<0.001)}\right.$ with the highest adjusted R-square of 0.269 .

The joint F-test shows that including interaction effect along with independent effects significantly improved model fit over the benchmark Model 2. The highest adjusted R-square of 27 per cent is achieved in Model 4.

\section{Discussion and concluding remarks}

Previous research emphasizes that the ability to create and transfer knowledge internally is one of the main competitive advantages of multinational firms compared with their domestic counterparts (Kogut and Zander, 1993). Yet, to realize the competitive potential of knowledge as a strategic resource, the internal knowledge transfer should be governed, i.e. influenced and directed through the deployment of governance mechanisms, in particular the formal aspects of the organization that can be manipulated by management, such as organization structure, information systems, 
standard operating procedures, accounting systems and other coordination mechanisms (cf. the KGA, as advocated by Grandori, 2001; Foss, 2007). Proponents of the KGA assert that HRM practices are critical antecedents of knowledge processes (Grandori, 2001; Foss, 2007).

On the other hand, researchers working in the field of HRM called for the transformation of the HRM system more than a decade ago, at which time they identified support to the process of organizational learning as the key strategic task facing the HRM function in many MNCs today (Pucik, 1988). Lado and Wilson (1994) suggested that HRM practices "can contribute to sustained competitive advantage through facilitating the development of competencies that are firm specific, produce complex social relationships, ... and generate organizational knowledge” (Lado and Wilson, 1994: 699).

Clearly, HRM practices and knowledge transfer are associated, but some important aspects of this interpretation and empirical support for the link are missing. From theoretical, empirical and managerial perspectives, the key issue is to understand why and how the deployment of specific HRM practices may best facilitate knowledge transfer within MNCs.

Towards this goal, this paper considered two groups of HRM practices whose employment facilitates knowledge transfer to the subsidiary. HRM practices were first identified conceptually (as recommended by MacDuffie, 1995; Youndt et al., 1996) and then factor analyzed to uncover the underlying factor structure associated with these practices (following Huselid, 1995). Two groups were identified - HRM practices influencing extrinsic motivation (performance-based rewards and recognition, financial support of degree-earning programs, performance management) 
and HRM practices influencing intrinsic motivation (job design, flexible working arrangements, transfers and career development).

We observed an individual positive and significant effect of HRM EXTR on knowledge transfer. This is in line with the general argument that extrinsic rewards encourage knowledge sharing. Our data did not provide any evidence for the individual effect of HRM INTR on knowledge transfer. We must be cautious in our interpretation of this result, since it may very well be due to the deficiencies in our measurement (in particular, HRM practices, low Cronbach Alpha) or data limitations (number of observations, single respondent per unit). On the other hand, intrinsically motivated employees may engage in activities to feel self-competent and selfdetermining. From an organizational viewpoint, intrinsically motivated people may present a risk by being more inclined to follow their own goals instead of the organizational goals. Further, it may be difficult for others to co-operate with highly intrinsically motivated employees, who may have a need to dominate, uncontrolled passion and a fanatic belief in their own ideas. So the use of intrinsic motivators alone may not explain much variance in achieving the organizational goal of transferring a higher degree of knowledge to the subsidiary. As Osterloh and Frey (2000) point out, organizations, with few exceptions, may not be interested in employees working in a highly motivated manner to achieve their own goals without considering the organizational goals. Instead, a preferred option would be that organizational members are motivated to contribute in a coordinated and organizational goal-seeking manner. Preconditions for intrinsic motivation are autonomy, a sense of competence and social relatedness. Thus, future research should also include organizational culture as a determinant when analyzing motivators for knowledge sharing. 
Further, one needs to keep in mind that "a factor may motivate performance in one (cultural) context and yet have no effect (or even a negative effect) in some other contexts” (Mead, 1998, p. 193). Some of the HRM practices I used to measure HRM INTR - flexible working arrangements, job enlargement, team-based job design - do not "travel” easily. For example, Brewster and Tregaskis (2003) show that the country of operation has the largest effect on the level of uptake of flexible practices. Additional analysis performed using this data showed no significant changes in either the direction of the relationships or the coefficients of the independent variables when a country dummy variable was introduced. The limited number of observations per country did not allow testing of the hypothesis separately for each country. Clearly, a similar study in which much larger countries are represented needs to be made in order to take some of the overlooked issues into account.

Few studies on HRM and knowledge transfer have considered the impact of complementarity among HRM practices on knowledge transfer, and those which have taken this factor into account have assumed that complementarity has a positive impact on all forms of knowledge-related performance. The paper challenges the view that complementarity among HRM practices is always positive for knowledge transfer. On the contrary, as was hypothesized and confirmed, when applied simultaneously, some HRM practices affect knowledge transfer process negatively. Such findings are in line with the arguments of Motivation Crowding Theory (Frey and Jegen, 2001), but do not make much sense for HR practitioners. Does this mean that extrinsic and intrinsic motivators should not be applied simultaneously to avoid crowding out effects? What can companies do to avoid negative complementarity? Should they choose between extrinsic and intrinsic motivators, and never apply them together? Not necessarily. Deci (1975) argues that extrinsic motivators always come 
first: "the simplest reason why people look first to external causes is that external forces are readily observable and therefore more reliable” (p.271). However, Vroom (1964) warns us: the relationship between extrinsic motivators and human performance of any kind might take the form of an inverted $U$ function. That is, performance is low when rewards are low, it reaches its maximum point under a moderate level of rewards and then drops off again even though the rewards are high. Perhaps at the last stage intrinsic rewards could be introduced to keep performance high. Such an approach echoes the idea of the Motivation-Work Cycle Match presented by Amabile (1993): the use of motivators should match the individual's basic motivational orientation toward work as well as job characteristics. Intrinsic motivators might be appropriate for certain stages of work when novelty and creativity are required, while extrinsic motivators can help "to ensure that the output will be timely, complete and useful” (Amabile, 1993: 196). From a practitioner's point of view, this would imply the need to examine different kinds of tasks and processes with the purpose of identifying the types of motivation needed - extrinsic or intrinsic. Additionally, the two fundamental types of motivation do not seem to have a supplementary relation and therefore, deliberate motivation management is very important (Osterloh and Frey, 2000).

The main limitation of the data is the use of a single respondent per unit. Consequently, I was able to capture only the intended HRM practices - those that are designed at the organizational level and "tied directly to the business strategy" (Wright and Niishi, 2006: 11). Although intended practices have been the focus of most HRM research, I subscribe to the recent call of Becker and Huselid (2006: 900), who argue that to advance, we need to push HRM scholars out of their "natural comfort zone”, which assumes the aggregation of individuals, the existence of an 
“average individual,” no differences in individual perception of external stimuli (intended HRM practices), and no differences in the reaction to those stimuli. Hence, future studies should aim at collecting individual level data to capture the variations in individuals' reaction to the implemented HRM practices (how HRM practices are “perceived and interpreted subjectively by each employee”, Wright and Niishi, 2006: 11). This would be most appropriate when discussing the individual responses to motivators. As Felin and Hesterly (2007) argue, individual level differences are likely to moderate, potentially strongly, the relation between HRM and knowledge transfer.

Data limitations aside, the analysis suggests that the axiom widely accepted in the HRM performance literature stating that "the more HRM practices a firm employs, the better it performs” may not apply to the HRM knowledge link. HRM practices should be designed to lead to certain outcomes. When outcomes change, the chosen HRM practices should be re-examined. Hence, one should not simply accept findings from the previous literature on HRM and (business) performance and substitute the performance variable with something "knowledge-related." Similarly, complementarity among HRM practices is not always positive; hence the reasons for potential complementarity should be examined carefully. To advance the field, it is recommended that groups of HRM practices be identified theoretically. In this regard, literature points to the possibility of expanding the framework linking HRM practices and knowledge transfer by introducing other individual level mediating variables, such as individual ability and (the use of) opportunities provided by the organization (Gerhart, 2005; Argote, McEvily and Reagans., 2003). This approach is also advocated in the emerging KGA approach (Osterloh and Frey, 2000; Grandori, 2001; Contractor and Ra, 2002; Nickerson and Zenger, 2004; Foss, 2007), which was used to frame the theoretical argumentation of this paper. Finally, introducing individual 
level mediating variables is a response to recent calls to focus on the role that individuals play in leveraging knowledge and improving our understanding of the micro-foundations needed to explain the emergence, existence, persistence and change of organizational-level variables (Felin and Foss, 2005; Felin and Hesterly, 2007) such as knowledge transfer.

To conclude, re-phrasing Guest (1997) we can now say with increasing confidence that HRM and knowledge transfer are linked, but "this is a skeletal finding and we need to put a lot of flesh on the bones” (p. 274). 


\section{References}

Amabile, T. (1993). Motivational synergy: Toward new conceptualizations of intrinsic and extrinsic motivation in the workplace. Human Resource Management Review, 3 (3), 185-201.

Argote, L., McEvily, B. \& Reagans, R. (2003). Introduction to the special issue on managing knowledge in organizations: Creating, retaining, and transferring knowledge, Management Science, 49 (4), v-viii.

Becker, B. \& Huselid, M. (1996). Methodological issues in cross-sectional and panel estimates of the human resource-firm performance link. Industrial Relations, 35, 400422.

Brewster, C. \& Tregaskis, O. (2003) Convergence or divergence of contingent employment practices? Evidence of the role of MNCs in Europe. In N- W. Cooke (ed.), Multinational companies and global human resource strategies, Greenwood: Quorum Books.

Cabrera, A. \& Cabrera, E. (2002). Knowledge sharing dilemmas. Organization Studies, 23, 687-710.

Cabrera, A., Collins, W.C., \& Salgado, J. F. (2006). Determinants of individual engagement in knowledge sharing. International Journal of Human Resource Management, 17, 245-264.

Cappelli, P. \& Neumark, D. (2001). Do “high-performance” work practices improve establishment-level outcomes? Industrial and Labor Relations Review, 54 (4), 737775.

Cohen, W. \& Levinthal, D. (1990). Absorptive capacity: A new perspective on 
learning and innovation, Administrative Science Quarterly, 35, 128-152.

Contractor, F. \& Wonchan, R. (2002). How knowledge attributes influence alliance governance choices. Journal of International Management, 8, 11-27.

Deci, E.L. (1972). Intrinsic motivation, extrinsic reinforcement, and inequity. Journal of Personality and Social Psychology, 22 (1), 113-120.

Deci, E. (1975). Intrinsic motivation. New York and London: Plenum Press.

Deci, E.L. \& Koestner, R. (1999). A meta-analytic review of experiments examining the effects of extrinsic rewards on intrinsic. Psychological Bulletin, 125 (6), 627-668.

Delaney, J. \& Huselid, M. (1996). The impact of human resource management practices on perceptions of organizational performance, Academy of Management Journal, 39 (4), 949-969.

Edstrom, A. \& Galbraith, J. (1977). Transfer of managers as a coordination and control strategy in multinational organizations, Administrative Science Quarterly, 22, 248-263.

Felin, T., \& Foss, N. (2005). Strategic organization: A field in search of microfoundations. Strategic Organization, 3, 441-455.

Felin, T. \& Hesterly, W. (2007). The knowledge-based view, nested heterogeneity, and new value creation: Philosophical considerations on the locus of knowledge. Academy of Management Review, 32 (1), 195-218.

Foss, N. (2007). The Emerging knowledge governance approach: Challenges and characteristics, Organization, 14 (1), 27-50.

Foss, N. \& Pedersen, T. (2002). Transferring knowledge in MNCs: The role of 
sources of subsidiary knowledge and organizational context. Journal of International Management, 8 (1), 49-67.

Frey, B. (1997). On the relationship between extrinsic and intrinsic work motivation. International Journal of Industrial Organizations, 15 (4), 427-439.

Frey, B. \& Jegen, R. (2001). Motivation crowding theory. Journal of Economic Surveys, 15 (1), 589-611.

Gerhart, B. (2005). Human resources and business performance: Findings, unanswered questions, and an alternative approach. Management Revue, 16 (2), 174185.

Grandori, A. (2001). Neither hierarchy nor identity: Knowledge governance mechanisms and the theory of the firm. Journal of Management and Governance, 5, 381-399.

Grandori, A. \& Kogut, B. (2002). Dialogue on organization and knowledge. Organization Science, 13, 224-232.

Guest, D. (1997). Human resource management and performance: A review and research agenda. International Journal of Human Resource Management, 8 (3), 263276.

Gupta, A. \& Govindarajan, V. (2000). Knowledge flows within MNCs. Strategic Management Journal, 21, 473-496.

Howard, G. (1994). Why do people say nasty things about self-reports? Journal of Organizational Behavior, 15 (5), 399-404.

Huselid, M. (1995). The impact of human resource management practices on turnover, productivity, and corporate financial performance. Academy of Management 
Journal, 38 (3), 635-672.

Huselid, M., Jackson, S., \& Schuler, R. (1997). Technical and strategic human resource management effectiveness as determinants of firm performance. Academy of Management Journal, 40 (1), 171-188.

Ichniowski, C., Shaw, K. \& Prennushi, G. (1997). The effects of human resource management practices on productivity: A study of steel finishing lines. The American Economic Review, June, 291-313.

Janssen, M. \& Mendys-Kamphorst, E. (2004). The price of a price: On the crowding out and in of social norms. Journal of Economic Behavior \& Organization, 55, 377395.

Kim, L. (2001). Absorptive capacity, co-operation, and knowledge creation: Samsung's leapfrogging in semiconductors. In Nonaka, I. and Nishiguchi, T. (eds.), Knowledge emergence - Social, technical, and evolutionary dimensions of knowledge creation, Oxford: Oxford University Press, 270-86.

Kohn, A.S. (1993). Why incentive plans cannot work. Harvard Business Review, 74 (5), 54-63.

Kogut, B. \& Zander, U. (1993). Knowledge of the firm and the evolutionary theory of the multinational corporation. Journal of International Business Studies, 24 (4), 625645

Lado, A. \& Wilson, M. (1994). Human resource systems and sustained competitive advantage: A competency-based perspective. Academy of Management Review, 19, 699-727.

Lane, P., Salk, J. \& Lyles, M. (2001). Absorptive capacity, learning, and performance 
in international joint ventures. Strategic Management Journal, 22 (12), 1139-1161.

Laursen, K. \& Foss, N. (2003). New HRM practices, complementarities, and the impact on innovation performance. Cambridge Journal of Economics, 27, 243-263.

Lyles, M. \& Salk, J. (1996). Knowledge acquisition from foreign parents in international joint ventures: An empirical examination in the Hungarian context. Journal of International Business Studies, Special Issue, 877-903.

MacDuffie, J. (1995). Human resource bundles and manufacturing performance: Flexible production systems in the world auto industry. Industrial \& Labor Relations Review, 48 (2), 197-221.

Mead, R. (1998). International management. Oxford: Blackwell Business

Milgrom, P. \& Roberts, J. (1990). The economics of modern manufacturing technology, strategy and organization. American Economic Review, 80, 511-528.

Milgrom, P. \& Roberts, J. (1995). Complementarities and fit: Strategy, structure and organizational change in manufacturing. Journal of Accounting and Economics, 19, 179-208.

Minbaeva, D. (2007). Knowledge transfer in multinational corporations. Management International Review, 4, 567-594.

Minbaeva, D., Pedersen, T., Bjorkman, I., Fey, C., \& Park, H. (2003). MNC knowledge transfer, subsidiary absorptive capacity and knowledge transfer. Journal of International Business Studies, 34 (6), 586-599.

Miner, J. \& Crane, D. (1995) Human resource Management: The strategic perspective. HarperCollins College Publishers.

Mowery, D., Oxley, J. \& Silverman, B. (1996). Strategic alliances and interfirm 
knowledge transfer. Strategic Management Journal, 17, 77-91.

Mudambi, R., Mudambi, S. M. \& Navarra, P. (2004). How to motivate knowledge workers: an empirical investigation of motivation crowding theory. The Fox School of Business and Management Discussion Paper, 316-04, March 2004.

Nickerson, J. and Zenger, T. (2004). A knowledge-based theory of the firm: The problem-solving perspective, Organization Science, 15 (6), 617-632.

Nielsen, B. \& Ciabuschi, F. (2003). Siemens ShareNet: Knowledge management in practice, Business Strategy Review, 14 (2), 33-40.

Osterloh, M. \& Frey, B. (2000). Motivation, knowledge transfer, and organizational forms. Organization Science, 11 (5), 538-550.

Osterloh, M., Frost, J. \& Frey, B. (2002). The dynamics of motivation in new organizational forms. International Journal of the Economics of Business, 9 (1), 6178.

Persson, M. (2006). The impact of operational structure, lateral integrative mechanisms and control mechanisms on intra-MNE knowledge transfer. International Business Review, 15, 547-569.

Pucik, V. (1988). Strategic alliances, organizational learning and competitive advantage: The HRM agenda. Human Resource Management, 27 (1), 77-93.

Ryan, R., \& Deci, E. (2000). Self-determination theory and the facilitation of intrinsic motivation, social development, and well-being. American Psychologist, 55, 68-78.

Schmitt, N. (1994). Method bias: The importance of theory and measurement. Journal of Organizational Behavior, 15 (5), 393-398.

Spector, P. (1994). Using self-report questionnaires in OB research: A comment on 
the use of a controversial method. Journal of Organizational Behavior, 15 (5), 385392.

Szulanski, G. (1996). Exploring internal stickiness: Impediments to the transfer of best practice within the firm. Strategic Management Journal, 17 (Winter Special Issue), 27-43.

Szulanski, G. (2003). Sticky knowledge: Barriers to knowing in the firm. SAGE Publications.

Tsang, E. (1999). The knowledge transfer and learning aspects of international HRM: An empirical study of Singapore MNCs. International Business Review, 8, 591-609 Vroom, V. \& Deci, E. (eds) (1970) Management and motivation. Penguin Books, London.

Whittington, R., Pettigrew, A., Peck, S., Fenton, E., \& Conyon, M. (1999). Change and complementarities in the new competitive landscape: A European panel study, 1992-1996. Organization Science, 10 (5), 583-600.

Wright, P., Dunford, B. \& Snell, S. (2001). Human resources and the resource based view of the firm. Journal of Management, 27, 701-721.

Wright, P. \& Nishii, L. (2006). Strategic HRM and organizational behavior: Integrating multiple levels of analysis. Working Paper 06-05, CAHRS Working Paper Series, Cornell University.

Youndt, M., Snell, S., Dean, J. \& Lepak, D. (1996). Human resource management, manufacturing strategy, and firm performance. Academy of Management Journal, 39 (4), 836-866. 


\section{Table 1. Measures}

\section{Variable}

Degree of knowledge transfer.

HRM practices influencing extrinsic motivation.
HRM practices influencing intrinsic motivation.
Label

DoKT

\section{HRM EXTR}

Please evaluate the degree of knowledge transfer from...

sister subsidiaries to your subsidiary: (a)marketing know-how, (b)distribution know-how, (c)packaging design/technology, (d)product designs, (e)process designs, (f)purchasing know-how and (g)management systems and practices.

the parent corporations (HQ) to your subsidiary: (a)marketing knowhow, (b)distribution know-how, (c)packaging design/technology, (d)product designs, (e)process designs, (f)purchasing know-how and (g)management systems and practices.

Likert type scale ranging from 1 - very low to 5 - outstanding. statement describes the HRM practices employed within your subsidiary.

There are extra rewards and recognition for superior performance

Employees are generally rewarded on the basis of the value of the job and their personal contribution to organizational performance

The company financially supports degree-earning programs at various colleges and universities

The performance management system in our company has an evaluative purpose of letting people know where they stand

Likert type scale ranging from 1 - never to 5 - always

HRM INTR Please mark the number that best indicates the degree to which each statement describes the HRM practices employed within your subsidiary.

We use different approaches to job design - such as job enlargement, job rotation, team-based job design

We use flexible working arrangements - such as flexitime, job sharing, part-time work - to best accommodate individual working arrangement preferences

Local nationals are often transferred to headquarters or other international operations

Career development in our company represents an ongoing and formalized effort of corporate management

Likert type scale ranging from 1 - never to 5 - always

Ownership (\% of foreign capital to total capital)

Mode of entry

MODE

$<25 \%$, 26-50\%, 51-75\%, 76-100\%. Responses were coded $1-76-100 \%$ of foreign capital, 0 - otherwise

Greenfield, Merging, Acquisition, Joint venture, Licensing, Franchising, WOS, Export and distribution, Other (please specify). Responses were coded 1 - Greenfield, 0 - otherwise

Subsidiary age AGE

Year of establishment. Responses were coded 1 - more than 10 years ago, 0 otherwise (from 2002)

Ability of

ABILITY

Please evaluate the ability of the knowledge receivers (your subsidiary's employees) to absorb new knowledge.

Likert type scale ranging from 1 - very low to 5 - outstanding 
Table 2. Factor loadings for HRM practices

HRM practice

The company financially supports degree-earning programs at various colleges and universities

There are extra rewards and recognition for superior performance

Employees are generally rewarded on the basis of the value of the job and their personal contribution to organizational performance.

Performance management system in our company has an evaluative purpose of letting people know where they stand

We use different approaches to job design - such as job enlargement, job rotation, team-based job design

We use flexible working arrangements - such as flexitime, job sharing, part-time work - to best accommodate individual working arrangement preferences

Local nationals are often transferred to headquarters or other international operations

Career development in our company represents an ongoing and formalized effort of corporate management

Eigenvalue

$\%$ of variance
HRM EXTR

$\underline{0.551}$

$\underline{0.850}$

$\underline{0.837}$

$\underline{0.636}$

0.294

$-0.128$

0.093

$\underline{0.727}$

0.470

$\underline{0.592}$

2.903

1.407

36.288

17.592

Table 3. Correlation matrix

MODE OWNERSHIP AGE ABILITY HRM EXTR HRM INTR DoKT

MODE $\quad 1.000$

OWNERSHIP $0.288^{*} \quad 1.000$

$\begin{array}{lll}\text { AGE } & -0.114 \quad-0.096 & 1.000\end{array}$

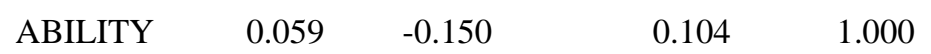

$\begin{array}{lllll}\text { HRM EXTR } & 0.054 & 0.096 & -0.254^{*} & 0.155\end{array}$

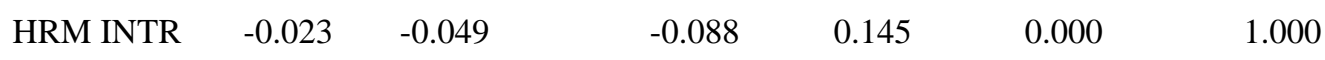

$\begin{array}{llllllll}\text { DoKT } & 0.025 & -0.120 & 0.011 & 0.232 * & 0.416^{* * *} & 0.154 & 1.000\end{array}$

$* * *-\mathrm{p}<0.001, *-\mathrm{p}<0.05$ 
Table 4. Regression analyses on knowledge transfer

\begin{tabular}{|c|c|c|c|c|c|c|c|c|}
\hline \multirow[t]{2}{*}{ Variables } & \multicolumn{2}{|l|}{ Model 1} & \multicolumn{2}{|l|}{ Model 2} & \multicolumn{2}{|c|}{ Model 3} & \multicolumn{2}{|l|}{ Model 4} \\
\hline & $\beta$ & s.e. & $\beta$ & s.e. & $\beta$ & s.e. & $\beta$ & s.e. \\
\hline Constant & $1.406 * *$ & 0.473 & $1.657 * * *$ & 0.469 & $1,308 *$ & 0.492 & $1.899 * * *$ & 0.467 \\
\hline MODE & -0.058 & 0.166 & -0.092 & 0.158 & -0.100 & 0.170 & -0.163 & 0.157 \\
\hline OWNERSHIP & -0.074 & 0.193 & -0.104 & 0.183 & -0.024 & 0.196 & -0.144 & 0.178 \\
\hline AGE & 0.062 & 0.153 & 0.132 & 0.147 & 0.045 & 0.157 & 0.160 & 0.145 \\
\hline ABILITY & $0.346^{* *}$ & 0.115 & $0.283^{*}$ & 0.116 & 0.371 & $0.121^{* *}$ & $0.229 *$ & 0.114 \\
\hline HRM EXTR & & & $0.238 * *$ & 0.074 & & & $0.254^{* * *}$ & 0.072 \\
\hline HRM INTR & & & & & 0.064 & 0.078 & $0.140^{\dagger}$ & 0.078 \\
\hline $\begin{array}{l}\text { HRM EXTR x } \\
\text { HRM INTR }\end{array}$ & & & & & & & $-0.201^{*}$ & 0.092 \\
\hline $\mathrm{F}$ & $2.602 *$ & & $4.634 * * *$ & & $2.329^{\dagger}$ & & $4.317 * * *$ & \\
\hline R-square & 0.146 & & 0.285 & & 0.167 & & 0.350 & \\
\hline $\begin{array}{l}\text { Adjusted R- } \\
\text { square }\end{array}$ & 0.090 & & 0.224 & & 0.095 & & 0.269 & \\
\hline
\end{tabular}




\section{SMG - Working Papers \\ www.cbs.dk/smg \\ 2003}

2003-1: Nicolai J. Foss, Kenneth Husted, Snejina Michailova, and Torben Pedersen: Governing Knowledge Processes: Theoretical Foundations and Research Opportunities.

2003-2: Yves Doz, Nicolai J. Foss, Stefanie Lenway, Marjorie Lyles, Silvia Massini, Thomas P. Murtha and Torben Pedersen: Future Frontiers in International Management Research: Innovation, Knowledge Creation, and Change in Multinational Companies.

2003-3: Snejina Michailova and Kate Hutchings: The Impact of In-Groups and OutGroups on Knowledge Sharing in Russia and China CKG Working Paper.

2003-4: Nicolai J. Foss and Torben Pedersen : The MNC as a Knowledge Structure: The Roles of Knowledge Sources and Organizational Instruments in MNC Knowledge Management CKG Working Paper.

2003-5: Kirsten Foss, Nicolai J. Foss and Xosé H. Vázquez-Vicente: “Tying the Manager's Hands": How Firms Can Make Credible Commitments That Make Opportunistic Managerial Intervention Less Likely CKG Working Paper.

2003-6: Marjorie Lyles, Torben Pedersen and Bent Petersen: Knowledge Gaps: The Case of Knowledge about Foreign Entry.

2003-7: Kirsten Foss and Nicolai J. Foss: The Limits to Designed Orders: Authority under "Distributed Knowledge" CKG Working Paper.

2003-8: Jens Gammelgaard and Torben Pedersen: Internal versus External Knowledge Sourcing of Subsidiaries - An Organizational Trade-Off.

2003-9: Kate Hutchings and Snejina Michailova: Facilitating Knowledge Sharing in Russian and Chinese Subsidiaries: The Importance of Groups and Personal Networks Accepted for publication in Journal of Knowledge Management.

2003-10: Volker Mahnke, Torben Pedersen and Markus Verzin: The Impact of Knowledge Management on MNC Subsidiary Performance: the Role of Absorptive Capacity CKG Working Paper.

2003-11: Tomas Hellström and Kenneth Husted: Mapping Knowledge and Intellectual Capital in Academic Environments: A Focus Group Study Accepted for publication in Journal of Intellectual Capital CKG Working Paper.

2003-12: Nicolai J Foss: Cognition and Motivation in the Theory of the Firm: Interaction or "Never the Twain Shall Meet"? Accepted for publication in Journal des Economistes et des Etudes Humaines CKG Working Paper.

2003-13: Dana Minbaeva and Snejina Michailova: Knowledge Transfer and Expatriation Practices in MNCs: The Role of Disseminative Capacity.

2003-14: Christian Vintergaard and Kenneth Husted: Enhancing Selective Capacity Through Venture Bases. 


\section{4}

2004-1: Nicolai J. Foss: Knowledge and Organization in the Theory of the Multinational Corporation: Some Foundational Issues

2004-2: Dana B. Minbaeva: HRM Practices and MNC Knowledge Transfer

2004-3: Bo Bernhard Nielsen and Snejina Michailova: Toward a Phase-Model of Global Knowledge Management Systems in Multinational Corporations

2004-4: Kirsten Foss \& Nicolai J Foss: The Next Step in the Evolution of the RBV: Integration with Transaction Cost Economics

2004-5: Teppo Felin \& Nicolai J. Foss: Methodological Individualism and the Organizational Capabilities Approach

2004-6: Jens Gammelgaard, Kenneth Husted, Snejina Michailova: Knowledge-sharing Behavior and Post-acquisition Integration Failure

2004-7: Jens Gammelgaard: Multinational Exploration of Acquired R\&D Activities

2004-8: Christoph Dörrenbächer \& Jens Gammelgaard: Subsidiary Upgrading? Strategic Inertia in the Development of German-owned Subsidiaries in Hungary

2004-9: Kirsten Foss \& Nicolai J. Foss: Resources and Transaction Costs: How the Economics of Property Rights Furthers the Resource-based View

2004-10: Jens Gammelgaard \& Thomas Ritter: The Knowledge Retrieval Matrix: Codification and Personification as Separate Strategies

2004-11: Nicolai J. Foss \& Peter G. Klein: Entrepreneurship and the Economic Theory of the Firm: Any Gains from Trade?

2004-12: Akshey Gupta \& Snejina Michailova: Knowledge Sharing in Knowledge-Intensive Firms: Opportunities and Limitations of Knowledge Codification

2004-13: Snejina Michailova \& Kate Hutchings: Knowledge Sharing and National Culture: A Comparison Between China and Russia

\section{5}

2005-1: Keld Laursen \& Ammon Salter: My Precious - The Role of Appropriability Strategies in Shaping Innovative Performance

2005-2: Nicolai J. Foss \& Peter G. Klein: The Theory of the Firm and Its Critics: A Stocktaking and Assessment

2005-3: Lars Bo Jeppesen \& Lars Frederiksen: Why Firm-Established User Communities Work for Innovation: The Personal Attributes of Innovative Users in the Case of Computer-Controlled Music

2005-4: Dana B. Minbaeva: Negative Impact of HRM Complementarity on Knowledge Transfer in MNCs

2005-5: Kirsten Foss, Nicolai J. Foss, Peter G. Klein \& Sandra K. Klein: Austrian Capital 
Theory and the Link Between Entrepreneurship and the Theory of the Firm

2005-1: Nicolai J. Foss: The Knowledge Governance Approach

2005-2: Torben J. Andersen: Capital Structure, Environmental Dynamism, Innovation Strategy, and Strategic Risk Management

2005-3: Torben J. Andersen: A Strategic Risk Management Framework for Multinational Enterprise

2005-4: Peter Holdt Christensen: Facilitating Knowledge Sharing: A Conceptual Framework

2005-5 Kirsten Foss \& Nicolai J. Foss: Hands Off! How Organizational Design Can Make Delegation Credible

2005-6 Marjorie A. Lyles, Torben Pedersen \& Bent Petersen: Closing the Knowledge Gap in Foreign Markets - A Learning Perspective

2005-7 Christian Geisler Asmussen, Torben Pedersen \& Bent Petersen: How do we Capture "Global Specialization" when Measuring Firms' Degree of internationalization?

2005-8 Kirsten Foss \& Nicolai J. Foss: Simon on Problem-Solving: Implications for New Organizational Forms

2005-9 Birgitte Grøgaard, Carmine Gioia \& Gabriel R.G. Benito: An Empirical Investigation of the Role of Industry Factors in the Internationalization Patterns of Firms

2005-10 Torben J. Andersen: The Performance and Risk Management Implications of Multinationality: An Industry Perspective

2005-11 Nicolai J. Foss: The Scientific Progress in Strategic Management: The case of the Resource-based view

2005-12 Koen H. Heimeriks: Alliance Capability as a Mediator Between Experience and Alliance Performance: An Empirical Investigation Into the Alliance Capability Development Process

2005-13 Koen H. Heimeriks, Geert Duysters \& Wim Vanhaverbeke: Developing Alliance Capabilities: An Empirical Study

2005-14 JC Spender: Management, Rational or Creative? A Knowledge-Based Discussion

\section{6}

2006-1: Nicolai J. Foss \& Peter G. Klein: The Emergence of the Modern Theory of the Firm

2006-2: Teppo Felin \& Nicolai J. Foss: Individuals and Organizations: Thoughts on a Micro-Foundations Project for Strategic Management and Organizational Analysis

2006-3: Volker Mahnke, Torben Pedersen \& Markus Venzin: Does Knowledge Sharing 
Pay? An MNC Subsidiary Perspective on Knowledge Outflows

2006-4: Torben Pedersen: Determining Factors of Subsidiary Development

2006-5 Ibuki Ishikawa: The Source of Competitive Advantage and Entrepreneurial Judgment in the RBV: Insights from the Austrian School Perspective

2006-6 Nicolai J. Foss \& Ibuki Ishikawa: Towards a Dynamic Resource-Based View: Insights from Austrian Capital and Entrepreneurship Theory

2006-7 Kirsten Foss \& Nicolai J. Foss: Entrepreneurship, Transaction Costs, and Resource Attributes

2006-8 Kirsten Foss, Nicolai J. Foss \& Peter G. Klein: Original and Derived Judgement: An Entrepreneurial Theory of Economic Organization

2006-9 Mia Reinholt: No More Polarization, Please! Towards a More Nuanced Perspective on Motivation in Organizations

2006-10 Angelika Lindstrand, Sara Melen \& Emilia Rovira: Turning social capital into business? A study of Swedish biotech firms' international expansion

2006-11 Christian Geisler Asmussen, Torben Pedersen \& Charles Dhanaraj: Evolution of Subsidiary Competences: Extending the Diamond Network Model

2006-12 John Holt, William R. Purcell, Sidney J. Gray \& Torben Pedersen: Decision Factors Influencing MNEs Regional Headquarters Location Selection Strategies

2006-13 Peter Maskell, Torben Pedersen, Bent Petersen \& Jens Dick-Nielsen: Learning Paths to Offshore Outsourcing - From Cost Reduction to Knowledge Seeking

2006-14 Christian Geisler Asmussen: Local, Regional or Global? Quantifying MNC Geographic Scope

2006-15 Christian Bjørnskov \& Nicolai J. Foss: Economic Freedom and Entrepreneurial Activity: Some Cross-Country Evidence

2006-16 Nicolai J. Foss \& Giampaolo Garzarelli: Institutions as Knowledge Capital: Ludwig M. Lachmann's Interpretative Institutionalism

2006-17 Koen H. Heimriks \& Jeffrey J. Reuer: How to Build Alliance Capabilities

2006-18 Nicolai J. Foss, Peter G. Klein, Yasemin Y. Kor \& Joseph T. Mahoney: Entrepreneurship, Subjectivism, and the Resource - Based View: Towards a New Synthesis

2006-19 Steven Globerman \& Bo B. Nielsen: Equity Versus Non-Equity International Strategic Alliances: The Role of Host Country Governance

\section{7}

2007-1 Peter Abell, Teppo Felin \& Nicolai J. Foss: Building Micro-Foundations for the Routines, Capabilities, and Performance Links 
2007-2 Michael W. Hansen, Torben Pedersen \& Bent Petersen: MNC Strategies and Linkage Effects in Developing Countries

2007-3 Niron Hashai, Christian G. Asmussen, Gabriel R.G. Benito \& Bent Petersen: Predicting the Diversity of Foreign Entry Modes

2007-4 Peter D. Ørberg Jensen \& Torben Pedersen: Whether and What to Offshore?

2007-5 Ram Mudambi \& Torben Pedersen: Agency Theory and Resource Dependency Theory: Complementary Explanations for Subsidiary Power in Multinational Corporations

2007-6 Nicolai J. Foss: Strategic Belief Management

2007-7 Nicolai J. Foss: Theory of Science Perspectives on Strategic Management Research: Debates and a Novel View

2007-8 Dana B. Minbaeva: HRM Practices and Knowledge Transfer in MNCs

2007-9 Nicolai J. Foss: Knowledge Governance in a Dynamic Global Context: The Center for Strategic Management and Globalization at the Copenhagen Business School

2007-10 Paola Gritti \& Nicolai J. Foss: Customer Satisfaction and Competencies: An Econometric Study of an Italian Bank

2007-11 Nicolai J. Foss \& Peter G. Klein: Organizational Governance

2007-12 Torben Juul Andersen \& Bo Berhard Nielsen: The Effective Ambidextrous Organization: A Model of Integrative Strategy Making Processes.

\section{8}

2008-1 Kirsten Foss \& Nicolai J. Foss: Managerial Authority When Knowledge is Distributed: A Knowledge Governance Perspective

2008-2 Nicolai J. Foss: Human Capital and Transaction Cost Economics.

2008-3 Nicolai J. Foss \& Peter G. Klein: Entrepreneurship and Heterogeneous Capital.

2008-4 Nicolai J. Foss \& Peter G. Klein: The Need for an Entrepreneurial Theory of the Firm.

2008-5 Nicolai J. Foss \& Peter G. Klein: Entrepreneurship: From Opportunity Discovery to Judgment.

2008-6 Mie Harder: How do Rewards and Management Styles Influence the Motivation to Share Knowledge?

2008-7 Bent Petersen, Lawrence S. Welch \& Gabriel R.G. Benito: Managing the Internalisation Process - A Theoretical Perspective.

2008-8 Torben Juul Andersen: Multinational Performance and Risk Management Effects: Capital Structure Contingencies. 
2008-9 Bo Bernard Nielsen: Strategic Fit and the Role of Contractual and Procedural Governance in Alliances: A Dynamic Perspective.

2008-10 Line Gry Knudsen \& Bo Bernhard Nielsen: Collaborative Capability in R\&D Alliances: Exploring the Link between Organizational and Individual level Factors.

2008-11 Torben Juul Andersen \& Mahesh P. Joshi: Strategic Orientations of Internationalizing Firms: A Comparative Analysis of Firms Operating in Technology Intensive and Common Goods Industries.

2008-12 Dana Minbaeva: HRM Practices Affecting Extrinsic and Intrinsic Motivation of Knowledge Receivers and their Effect on Intra-MNC Knowledge Transfer. 